\title{
Penerapan Nilai Pendidikan Islam dalam Keluarga Melalui Prophetic Parenting dalam Pembentukan Akhlak Anak Usia Emas di Desa Bukit Barisan
}

\author{
Karliana Indrawari \\ Institut Agama Islam Negeri Curup \\ karlianaindrawari@gmail.com \\ Madi Apriadi \\ Institut Agama Islam Negeri Curup \\ madiapriadi@gmail.com \\ Nur Jannah \\ Institut Agama Islam Negeri Curup \\ nurjannahtaklim@gmail.com \\ Diah \\ Institut Agama Islam Negeri Curup \\ diah@gmail.com
}

\begin{abstract}
The religion of parents in Bukit Barisan is still lacking and parents' lack of time at home because they are busy working in the garden and lack of control over the children, causing a child to feel free and lack of education from parents. This study aims to determine the problems of parents in the formation of morals in children and to find out how prophetic parenting in the family forms the morals of children in Bukit Barisan Village. This type of research is descriptive analytical, with data collection techniques through observation, interviews, and documentation. While the data analysis techniques include data reduction, data presentation and drawing conclusions. The results of the first study, the problems faced by parents in the formation of morals in children in Bukit Barisan Village are the lack of understanding of parents about religion and lack of supervision from parents. Second, the formation of children's morals through inculcating the values of Islamic education through prophetic parenting, namely parenting in the form of qudwah hasanah (good examples), al-'adah (habituations), mauidzah hasanah (good advice), uqubah wa kataah (proportionate), and al-'adah. mulahadzah (attention).
\end{abstract}

Keywords: Prophetic Parenting; Morals; Golden Age

Abstrak: Agama orang tua di Bukit Barisan masih kurang dan kurangnya waktu orang tua di rumah karena sibuk bekerja di kebun dan pengontrolan pada anak-anak masih kurang, sehingga menyebabkan seorang anak merasa bebas dan kurangnya pendidikan dari orang tua. Penelitian ini bertujuan untuk mengetahui problematika orang tua dalam pembentukan akhlak pada anak dan Untuk mengetahui bagaimana prophetic parenting dalam keluarga untuk membentuk akhlak anak di Desa Bukit Barisan. Jenis penelitian ini bersifat deskriptif analistik, dengan teknik pengumpulan data melalui observasi, wawancara, dan dokumentasi. Sedangkan tekhnik analisis data meliputi reduksi data, penyajian data dan penarikan kesimpulan. Hasil penelitian pertama, problematika yang dihadapi orang tua dalam pembentukan akhlak pada anak di Desa Bukit Barisan adalah kurangnya pemahaman orang tua tentang agama dan kurangnya pengawasan dari

Belajea: Jurnal Pendidikan Islam Vol. 6, No 2, 2021; 181-194

p-ISSN 2548-3390; e-ISSN 2548-3404, DOI: 10.29240/belajea.v6i2.3417

available online at:http://journal.iaincurup.ac.id/indek.php/belajea 
orang tua. Kedua pembentukan akhlak anak melalui penanaman nilai pendidikan Islam melalui prophetic parenting yaitu pola asuh berupa qudwah hasanah (contoh yang baik), al-'adah (pembiasaan), mauidzah hasanah (nasihat yang baik), uqubah wa ujarah (proporsional), serta almulahadzah (perhatian).

Kata Kunci: Prophetic Parenting; Akhlak; Golden Age

\section{PENDAHULUAN}

Masa golden age terletak pada masa anak usia dini dimana usia yang sangat penting bagi perkembangan anak yang berkesinambungan. Fase golden age anak mengalami pertumbuhan otak, intelegensi, keprbadiaan, memori dan aspek perkembangan lainnya. ${ }^{1}$ Masa golden age merupakan masa dimana individu terus memperoses perkembangannya dengan pesat, sehingga masa ini menentukan perkembangan anak selanjutnya. ${ }^{2}$ Masa golden age membutuhkan pendidikan awal dimana pendidikan awal berperan penting bagi pertumbuhan dan perkembangan anak selanjutnya. Pendidikan awal golden age didapatkan melalui keluarga.

Keluarga merupakan tempat pertama dan utama bagi anak dalam memperoleh pendidikan. keluarga juga merupakan tempat anak mengenal dan mulai belajar berbagai hal mengenai akhlak, keyakinan, dan lain sebagainya. Anak-anak memperoleh pembelajaran dari kedua orang tuanya, anak akan mendengar, melihat dan melakukan sesuatu sesuai dengan orang tua mereka contohkan dan lakukan. Peran keluarga khususnya ayah dan ibu terhadap anak tidak hanya sebatas perkembangan ekonomi dan sosialnya saja, melainkan bagaimana cara keluarga memaksimalkan dalam mendidik anak-anaknya. Hal ini untuk mencegah dampak buruk dan hal-hal lain yang akan timbul di sekeliling mereka. Betapa pentingnya pendidikan akhlak dalam keluarga sehingga orang tua dituntut untuk memperingatkan dan menjaga anak-anaknya dari api neraka. orang tua harus menjadi teladan yang baik bagi si anak. Kegiatan yang positif dan baik harus menjadi kebiasaan sehari-hari sehingga anak terbiasa melakukan perbuatan baik juga. ${ }^{3}$

Pendidikan di dalam keluarga merupakan sebuah pintu gerbang utama dan pertama bagi seorang anak dan orangtualahnyalah yang menjadi madrasah pertama atau sekolah pertama bagi seorang anak. Salah satu tanggung jawab

${ }^{1}$ Muhammad Taufiqurrahman, Prophetic Parenting Mencetak Pendidik Berkarakter Dalam Pendidikan Anak Usia Dini, Al Fitrah Journal Of Early Childhood Islamic Education Vol.1 No.2 Januari 2018, hal 91

${ }^{2}$ Ulfiani Rahman, Karakteristik, perkembangan Anka usia Dini, Jurnal Lentera Pendidikan Vol. 12 N0 1 Juni 2020, hal. 47

3 Yuni Ariska, Mohammad Afifulloh, Lia Nur Atiqoh Bela Dina, PERAN KELUARGA DALAM PENDIDIKAN AKHLAK ANAK (STUDI KASUS ANAK USLA 612 TAHUN DI KELURAHAN WONOKOYO RT 03 RW 02 MALANG), VICRATINA: Jurnal Pendidikan Islam, Volume 5 Nomor 4 Tahun 2020, hal. 1664. 
yang harus diberikan orangtua atas anak yang diamanahkan kepada mereka adalah dengan berusaha mendidik mereka sebaik-baiknya melalui pola asuh yang tepat, karena tanpa pendidikan dan pola asuh yang tepat, rasanya mustahil mereka akan menjadi generasi yang berkualitas yang shalih dan shalihah. ${ }^{4}$

Sebagaimana firman Allah yang Artinya: "Hai orang-orang yang beriman, periharalah dirimu dan keluargamu dari api neraka yang bahan bakarnya adalah manusia dan batu; penjaganya malaikatmalaikat yang kasar; keras, dan tidak mendurhakai Allah tergadap apa yang diperintahkan-Nya kepada mereka dan selalu mengerjakan apa yang diperintahkan". (Q.S AtTahrim: 06)

Dalam lingkungan keluarga, yang pertama kali dibentuk dan didik adalah akhlak anak. Dalam proses pendidikan Islam Akhlak selalu menjadi sasaran utama, karena akhlak dianggap sebagai dasar bagi keseimbangan kehidupan manusia yang menjadi penentu keberhasilan bagi potensi pedagogis yang lain. Pembentukan akhlak anak dalam Islam menjadi pilar utama tujuan pendiidkan. Untuk mewujudkan pembentukan akhlak pada anak al Ghazali menawarkan sebuah konsep pendidikan yang bertujuan mendekatkan diri kepada Allah. ${ }^{5}$

Abdullah bin Amr bin Ashz meriwayatkan bahwa Rasululullah SAW. pernah bersabda Artinya: "Sesungguhnya yang terbaik diantara kalian adalah yang paling baik akblaknya "(HR. al-Bukhari, 10/378 dan Muslim no. 2321)

Perlu adanya pengajaran, bimbingan dan pengarahan dengan baik untuk membentuk kepribadian yang mulia dan mengembangkan potensi yang dimiliki manusia dalam kehidupan bermasyarakat. Karena dalam Islam telah mengajarkan untuk menciptakan masyarakat baik harus dimulai dari manusia yang memiliki Akhlakul Karimah ${ }^{6}$

Mengingat pentingnya akhlak pada anak maka orang tua sangat berperan penting dalam pembentukan akhlak pada anak-anaknya. Oleh karena itu, dengan adanya bimbingan dari orang tua dalam pembentukan akhlak maka akan membentuk perilaku atau tingkah laku anak yang mencerminkan akhlak yang dapat mendekatkan dirinya kepada Allah swt.

Pengembangan akhlak anak pada usia emas (golden age), sangat menetukan perkembangan potensi anak kedepannya terbukti dengan hasil

${ }^{4}$ Hanan H. Anak Shalih, Investasi Dunia Akherat, Hidayatullah Edisi 03/XVIII/Juli 2005, hlm 26- 27.

${ }^{5}$ Nur Ainiyah. Pembentukan Karakter Melalui Pendidikan Agama Islam. Jurnal Al-Ulum, (2013). Hal. 25-38

${ }^{6}$ Siti Halimah. "Upaya Guru dalam Pembentukan Akblak. Anak di Raudlotul Athfal Baipas Roudlotul Jannah Kota Malang." Jurnal Dewantara, (2019), hal 81-86 
penelitian menunjukkan bahwa sekitar 50\% variabilitas kecerdasan orang dewasa sudah terjadi ketika berada pada usia 4 tahun. Peningkatan 30\% berikutnya terjadi pada usia 8 tahun, dan 20\% sisanya pada pertengahan atau akhir dasawarsa kedua. Oleh karenanya sudah sepatutnya pengembangan akhlak dimulai dari dalam keluarga yang merupakan lingkungan pertama bagi pertumbuhan akhlak anak. ${ }^{7}$

Orang tua di Desa Bukit Barisan masih memiliki problem atau masalah dalam pembentukan akhlak pada anak mereka, yang mana pemahaman tentang agama orang tua masih dapat dikatakan kurang. Misalnya, disekolah anak mendapatkan pelajaran bahwa shalat itu wajib untuk dikerjakan 5 kali sehari, sementara di rumah anak melihat orang tuanya sering meninggalkan shalat. Kurangnya waktu orang tua di rumah karena sibuk bekerja di kebun dan pengontrolan pada anak-anak mereka yang masih kurang, sehingga menyebabkan seorang anak merasa bebas dan kurangnya pendidikan dari orang tua mereka. Oleh karena itu, orang tua harus dapat mengatur waktu mereka untuk membentuk akhlak sehingga anak-anak mereka mempunyai perilaku dan akhlak yang baik.

Karena itulah dipandang perlu dilakukan pembentukan akhlak anak dengan penanaman nilai pendidikan Islam melalui proptebic parenting. Proptebic parenting adalah mendidik anak dengan mencontoh dan berkiblat pada metodemetode yang dilakukan Rasulullah SAW., baik mendidik keluarga maupun sahabat beliau. Konsep Prophetic mengacu pada uswah hasanah yang terdapat pada diri Nabi Muhammad SAW. Metode yang diterapkan dalam prophetic parenting diantaranya metode keteladanan, metode dengan Pujian, metode dengan nasehat, metode perhatian, dan metode pembiasaan, sanjungan dan kisah, serta metode hukuman. ${ }^{8}$

Sebagaimana terdapat dalam jurnal Yulia Hairina "Prophetic Parenting Sebagai Model Pengasuban dalam Pembentukan Karakter (Akblak)" Vol No 12016. Berdasarkan hasil penelitian penting di dalam kelurga membutuhkan model pengasuhan aatau parenting demi perekmebngan akhlak atau karakter anak. Apa yang dilakukan Rasulullah SAW. baik dalam mengasuh maupun cara mendidik patut kita contoh karena Rasulullah SAW. sosok figure yang terbaik kita ikuti seluruh umat manusia. Adapun metode-metode pendidikan karakter atau akhlak yang dicontohkan Rasul bagi anak yang dapat diterapkan adalah keteladanan,

7 Yulia Hairina, Prophetic Parenting sebagai Model Pengasuban dalam Pembentukan Karakter (Akblak) Anak, Studia Insania, April 2016 Vol 4 N0 1 hal. 86

8 Yulia Hairina, Prophetic Parenting sebagai Model Pengasuban dalam Pembentukan Karakter (Akblak) Anak, Fakultas Ushuluddin dan Humaniora IAIN Antasari Banjarmasin, 2016, Vol. 4. 
pembiasaan, pemberian nasihat, pemberian sanjungan dan hukuman, memberikan perhatian dan pendidikan melalui metode kisah. ${ }^{9}$

Jurnal Muhammad Taufiqurrahman dengan judul Prophetic Parenting Mencetak Pendidik Berkarakter Dalam Pendidikan Anak Usia Dini Vol. 1 No. 2 2018. Berdasarkan hasil penelitian pendidik yang sukses dan baik adalah pendidik yang memiliki akhlak baik dan memahami bagaimana mendalami metode pengajaran yang dilakukan Rasul yang dijadikan rujukan dan bisa diterapkan pada anak usia dini. ${ }^{10}$

Selanjutnya jurnal Sutipyo Ru'iya, Teguh Santoso Dody Sb, Herina Octaviani Saputri, dengan judul Penguatan Prophetic Parenting Bagi Orangtua Di Kelurahan Patangpuluhan Wirobrajan Yogyakarta Community Engagement \& Emergence Journal Volume 2 Nomor 2 2021. Berdasarkan hasil penelitian bahwa peneliti mengenalkan kepada orang tua yang di kelurahan patangpuluhan pola pengasuhan yang diajarkan Rasulullah yaitu: qudwah hasanah (contoh yang baik), al-'adab (pembiasaan), mavidzah hasanah (nasihat yang baik), uqubah wa ujarah (proporsional), serta al-mulahadzah (perhatian). ${ }^{11}$

Tujuan penelitian yang ingin dicapai peneliti adalah sebagai berikut yaitu untuk mengetahui apa saja problematika yang dihadapi orang tua dalam pembentukan akhlak pada anak di Desa Bukit Barisan, Untuk mengetahui bagaimana prophetic parenting dalam keluarga untuk membentuk akhlak anak di Desa Bukit Barisan.

Jenis penelitian ini adalah penelitian lapangan (field research) yang bersifat deskriptif analitik yaitu uraian naratif yang menggunakan pendekatan kualitatif (Muri, 2017:335). Penelitian lapangan (field research) ini meneliti objek secara langsung lokasi yang akan diteliti yang bertempat di Desa Bukit Barisan Kec. Merigi, untuk memperoleh informasi apa saja problematika yang dialami orang tua dalam pembentukan akhak anak di Desa Bukit Barisan secara lebih mendalam.

Subjek penelitian dalam penelitian ini adalah orang tua yang mempunyai anak usia 7-12 tahun yang berada di Dusun 3 Desa Bukit Barisan Kec. Merigi Kab. Kepahiang. Dalam penelitian ini sumber datanya adalah Data primer yaitu

\footnotetext{
9 Yulia Hairina "Prophetic Parenting Sebagai Model Pengasuban dalam Pembentukan Karakter (Akblak)" Jurnal Studia Insania Vol No 12016.

10 Muhammad Taufiqurrahman, Prophetic Parenting Mencetak Pendidik Berkarakter Dalam Pendidikan Anak Usia Dini, vol 1 No 2 2018, Al Fitrah Journal Of Early Childhood Islamic Education

${ }^{11}$ Sutipyo Ru'iya, Teguh Santoso Dody Sb, Herina Octaviani Saputri, Penguatan Prophetic Parenting Bagi Orangtua Di Kelurahan Patangpuluhan Wirobrajan Yogyakarta, Community Engagement \& Emergence Journal Volume 2 Nomor 22021.
} 
orangtua yang memiliki anak usia 7-12 tahun di Desa Bukit Barisan di Dusun 3 Kec. Merigi Kab. Kepahiang dan sumber data sekunder adalah buku-buku penelitian terdahulu dan sumber lain yang berhubungan dengan penelitian yang dianggap relevan terhadap penelitian ini teknik pengumpulan data yang pertama adalah observasi yang dilakukan bertujuan untuk mendapatkan data yang lebih akurat dan untuk menambah informasi tentang problematika orang tua dalam pembentukan akhlak anak di Desa Bukit Barisan. Wawancara yang dilakukan adalah orang tua anak yang memiliki anak dengan rentang usia 7-12 tahun yang berada di dusun 3 Desa Bukit Barisan. Dokumentasi ialah digunakan untuk memperoleh data-data tentang struktur desa seperti profil desa, dan kondisi demografi penduduk. Setelah peneliti mendapatkan data dari proses observasi, wawancara maupun dokumentasi, Maka selanjutnya peneliti melakukan analisis data, yaitu proses mengatur secara sistematis data-data yang telah didapat, mengorganisasikan ke dalam suatu pola, kategori, memilah data yang penting untuk membuat kesimpulan dan uraian dasar sehingga mudah dipahami.

\section{PEMBAHASAN}

\section{Problematika Orang Tua dalam Pembentukan Akhlak pada Anak di Desa Bukit Barisan}

\section{Kurangnya Pemahaman Agama orang Tua}

Permasalahan yang dialami orang tua dalam pembentukan akhlak anak di Desa Bukit Barisan adalah kurangnya pemahaman orang tua tentang agama. Tugas orang tua mengenalkan Allah dan menanamkan nilai-nilai agama kepada anak. Kesalahan orang tua jika tidak mengenalkan Allah SWT. kepada anak dan ini adalah kesalahan fatal yang telah dilakukan orang tua, jika keinginannya menjadikan sang buah hati menjadi anak yang shaleh tapi sudah merasa puas dengan hanya menitipkan anak ke sekolah-sekolah agama, mencekoki anak dengan perintah perintah maupun larangan-larangan dalam ajaran agamanya atau diberikan guru ngaji private, sedangkan orang tua tidak menunjukkan contoh teladan keindahan agama yang diajarkannya.

Sebagaimana yang di sampaikan oleh ibu Titis bahwa anak saya belajar tentang kalimat tauhid ditempat dia mengaji. Di TPQ. Saya hanya mengingatkan mbak kalo sholat itu penting dan juga sebagai bekal kita nanti ketika sudah meninggal, kalo mengajari ibadah sholat, puasa, zakat dan ibadah haji itu anak saya belajar ditempat TPQ mbak. Kadang-kadang iya kadang-kadang enggak juga mbak karena anak saya lebih suka bermain handphone. Soalnya saya sendiri sering lupa bacaan zikir mbak jadinya saya enggak mengajarkan kepada anak mbak. Iya saya ajarkan yang mudah-mudah dulu seperti tidak melawan orang tua dan meningatkan pergi mengaji." 
Hal senada disampaikan oleh orang tua dari Resti Utami yaitu Ibu Suwarti yang mengatakan bahwa: Iya tapi hanya sekedar mengulang pelajaran yang diberikan disekolah, saya mempertanyakan apa yang dingat tentang materi yang dikasih gurunya. Iya pasti, tapi saya hanya sekedar mengingatkan untuk selalu menjaga sholat, puasa untuk melatih sejak kecil agar terbiasa. Belum, anak saya masih belajar iqra. saya hanya membantu membiasakan anak saya untuk rajin mengaji dimasjid, karena saya kadang tidak ada waktu lagi untuk mengajarkannya, jadi saya serahkan dengan guru ngajinya. Tidak. saya fikir itu sudah diajarkan di sekolah dan guru mengajinya. kalo saya lagi ada waktu saya menghidupkan siaran TV anak yang ada pengajarannya tentang zikir dan sebagainya. Tidak, karena pengetahuan saya juga kurang jadi saya tidak mengajarkannya, paling saya suruh anak saya untuk rajin membaca buku materi disekolahnya saja."

Menurut bapak Asril Sukarman orang tua dari Fharizi Qhoir Pratama beliau mengungkapkan bahwa mereka kurang memiliki waktu yang cukup untuk mengajari anaknya pengetahuan tentang agama. Contohnya, untuk mengajari anak tentang ilmu tauhid, bapak Asril menyerahkanya di tempat TPQ dan di sekolah. Begitu juga mengajarkan anak untuk menjalankan ibadah shalat pun, bapak arsil menyerahkannya kepada guru sekolah dan guru mengajinya.

Berdasarkan hasil penelitian diatas bahwa masih ada orang tua yang melalaikan kewajibannya. Orang tua hanya menyuruh anaknya namun tidak mengajari langsung kepada anak. Mereka mengarahkan anaknya untuk belajar di disekolah maupun di TPQ. Seharusnya orang tua bukan hanya menyuruh anaknya saja tetapi orang tua ikut serta dalam melaksanakan ibadah seperti mengajak anak melaksanakan shalat berjamaah, berzikir setelah sholat, mencontohkan berperilaku baik sesuai ajaran islam dan mengajari anak mengaji.

\section{Kurangnya Pengawasan Orang Tua}

Tugas orang tua adalah mendidik, mengajar, membimbing dan memberikan pengawasan. Pengawasan orang tua lebih kepada kehidupan seharihari anak ketika berada di dalam maupun di luar rumah. Ada tiga macam pengawasan yang menjadikan anak tumbuh menjadi orang yang shaleh, di antaranya: Pengawasan Terhadap Ibadahnya, pengawasan Terhadap Perilaku Kesehariannya dan pengawasan Terhadap Prestasi Belajar.

Ibu Asmi selaku orang tua dari Ishak Widha Darma mengatakan bahwa: Untuk pengawasan tidak terlalu bisa saya awasi Karena saya lebih banyak di kebun daripada di rumah. Jika saya sedang di rumah dan tidak bekerja saya bisa mengawasi tapi kalau saya sedang di Kebun saya serahkan pengawasannya kepada kakak laki-lakinya. Saya sudah berusaha agar prestasi belajarnya lebih 
baik dari sebelumnya, ketika malam hari saya tidak sibuk saya bantu dia untuk mengerjakan PR dari sekolah."

Hal yang sama pun dijawab oleh bapak Asril Sukarman beliau mengatakan bahwa: Kadang-kadang iya mbak, kalau sholat jumat selalu saya ingatkan untuk pergi kemasjid dan apabila dia tidak mau, saya tidak segan untuk memarahinya, biarlah dia menangis tapi ujung-ujungnya dia mau pergi sholat jumat ke masjid. Kurang mbak karena kami sibuk bekerja dikebun, sesudah pulang dari kebun sering saya amati tingkah laku anak saya dan alhamdulilah saya tidak menemukan hal-hal yang tidak saya inginkan. Kalau masalah sekolah saya serahkan ke ibunya mbak, ibunya selalu mengawasi pelajaran anak setiap hari, dan anak saya selalu belajar ketika malam hari.”

Berdasarkan hasil wawancara tersebut dapat diketahui bahwa sebagian orang tua yang berada di Dusun III Desa Bukit Barisan bermata pencaharian sebagai petani yang mengakibatkan masih bayak orang tua yang kurang dalam mengawasi atau mengontrol kegiatan sehari-hari anak, namun ada juga orang tua yang memberikan pengawasan dan memperhatikan anaknya ketika sedang tidak bekerja di kebun.

\section{Memberi Kebebasan Kepada Anak}

Dalam membentuk akhlak pada anak lingkungan masyarakat adalah salah satu lingkungan yang mempengaruhi, karena anak melakukan interaksi dengan lingkungan sekitanya. Apabila lingkungan masyarakat anak kurang baik maka dapat mempengaruhi akhlak anak menjadi kurang baik. Teman merupakan salah satu penyebab yang dapat mempengaruhi anak. Anak cenderung berperilaku yang sama dengan teman sebayanya. Bermain di luar rumah dengan teman sebaya sudah menjadi rutinitas anak sehari-hari. Teman-teman anak yang ada dilingkungan sekitar tidak semuanya dapat berperilaku baik sehingga secara tidak langsung anak sangat mudah terpengaruh.

Hasil wawancara dengan Ibu Suwarti orang tua dari Resti Utami beliau mengatakan: "Saya tidak melarang anak saya berteman dengan siapapun selama dia tidak melakukan hal yang tidak baik, tetapi saya memberikan keterbatasan agar dia tidak lupa waktu untuk belajar dan mengaji, karena hanya disitulah dia bisa belajar, saya tidak bisa memberikan pengajaran penuh karena pengetahuan saya juga terbatas ditambah setiap hari saya kerja"

Berdasarkan hasil wawancara dengan Ibu Suwarti di ketahui bahwa beliau tidak melarang anaknya untuk berteman dengan siapapun selama anaknya tidak meniru hal yang tidak baik dari temanya. Tetapi beliau tetap mengawasi anaknya dikarenakan jika anak bergaul dengan teman yang salah maka anak akan mengikuti dan meniru perilaku dari temannya. 
Berdasarkan hasil penelitian diketahui bahwa orang tua di Bukit Barisan memberikan kebebasan pergaulan kepada anak akan tetapi orang tua tetap mengawasi dikarena jika anak bergaul dengan teman yang salah maka anak akan mengikuti dan meniru perilaku dari temannya.

\section{Prophetic Parenting Dalam Keluarga Untuk Membentuk Akhlak Anak di Desa Bukit Barisan}

Masa golden age bagi anak-anak adalah masa yang sangat penting utuk kita perhatikan bagi orang tua. Masa dimana kewajiban orang tua memberikan pendidikan yang terbaik demi pertumbuhan dan perkembangan potensi akhlak anak. Pembentukan akhlak anak dimulai dari lingkungan keluarga, dimana keluarga adalah gerbang pertama dan utama anak mengenal segala hal terutama akhlak dan karakter anak.

Rasulullah telah memberikan contoh dan uswah dalam mendidik akhlak anak yang dikenal dengan prophetic parenting. Cara yang dilakukan Rasulullah Saw adalah mendidikan anak dengan memberikan contoh yang baik dalam kehidupan sehari-hari, memberikan nasehat jika menemukan kesalahan-kesalahan yang dilakukan anak, memberikan pembiasaan yang baik untuk anak, memberikan perhatian yang terbaik bagi anak-anak, serta proporsional.

Prophetic parenting dimulai dari membimbing setiap orang tua yang mendidik anak mulai dari mereka belum disebut orang tua. Maksudnya adalah prophetic parenting membimbing setiap pemuda dan pemudi untuk mempersiapkan diri mereka sebaik mungkin sebelum mereka menikah dan mempunyai anak. Menyiapkan segala ilmu yang lurus sebelum menjadi orang tua sangatlah penting karena dengan ilmu yang lurus setiap orang tua akan sukses dalam memimpin atau mengarahkan keluarganya menuju kebaikan. Persiapan ilmu tersebut berlaku baik untuk seorang pemuda yang akan menjadi suami maupun pemudi yang akan menjadi seorang istri. Orang tua (khususnya orang tua muslim) memiliki andil terbanyak dalam misi pendidikan karakter

Rasulullah mendidik anak dalam bidang akidah, ibadah, akhlak dan halhal yang bersifat persoalan kemasyarakatan. Rasulullah SAW. memerintahkan kepada kedua orangtua untuk menjadi suri teladan yang baik dalam bersikap dan berperilaku jujur dalam berhubungan dengan anak. Anak-anak akan selalu memperhatikan dan meneladani sikap dan perilaku orang dewasa. Apabila mereka melihat kedua orangtua berperilaku jujur, mereka akan tumbuh dalam kejujuran dan demikian seterusnya. Untuk itu kedua orangtua selalu dituntut untuk menjadi suri teladan yang baik bagi anak-anaknya

Rasulullah SAW. selalu memperhatikan secara teliti tentang waktu dan tempat yang tepat untuk mengarahkan anak, membangun pola pikir anak, 
mengarahkan perilaku anak dan menumbuhkan akhlak yang baik pada diri anak. Tiga waktu mendasar dalam memberi pengarahan kepada anak yaitu Dalam Perjalanan Rasulullah shallahu 'alaihi wa sallam Waktu Makan Pada waktu ini, Nabi SAW. makan bersama anak-anak. Beliau memperhatikan dan mencermati sejumlah kesalahan. Kemudian Beliau memberi pengarahan dengan metode yang dapat mempengaruhi akan dan meluruskan kesalahan-kesalahan yang dilakukan waktu anak sakit. Rasulullah saw menjenguk seorang anak yahudi yang sedang sakit dan mengajaknya masuk Islam. Kunjungan itu menjadi kunci cahaya bagi anak tersebut.

Rasulullah saw mewasiatkan kepada kedua orangtua untuk bersikap adil dan menyamakan pemberian, sebagaimana dalam sebuah hadits yang berbunyi: "Bersikap adillah terhadap anak-anak kalian, bersikap adillah terhadap anak-anak kalian, bersikap adillah terhadap anak-anak kalian". Nabi saw bahkan sampai tiga kali mengulangi perintah agar adil kepada anak-anak. Orangtua dituntut agar senantiasa adil dalam segala hal, baik dalam pemberian hadiah atau hal lainnya. Rasulullah SAW. melarang keras sikap orangtua yang tidak berperilaku adil di antara anakanaknya. Bahkan beliau mengingatkan sahabatnya untuk bertakwa kepada Allah SWT. tatkala ada di antara mereka yang kurang adil terhadap anakanak mereka.

Menunaikan hak anak dan menerima kebenaran dirinya dapat menumbuhkan perasaan positif dalam dirinya dan sebagai pembelajaran bahwa kehidupan itu adalah memberi dan menerima. Hendaklah orangtua selalu mendoakan kebaikan untuk anaknya. Waktu-waktu yang mustajab untuk berdoa adalah di pertengahan malam terakhir dan setiap selesai shalat fardhu. Mendoakan anak dengan doa yang baik adalah sangat penting, karena mendoakan anak dengan segala kebaikan adalah hadiah terbaik untuk anak, mengingat anak adalah titipan dari Allah SWT. sehingga orangtua harus menjaga, merawat, serta mengarahkannya untuk dapat meraih kesuksesan baik di dunia maupun di akhirat.

Lingkungan pertama yang ditemui seorang anak adalah keluarga yang terdiri dari ayah, ibu, dan saudara. Dalam interaksinya seorang anak mengadaptasi dari apa yang dilihat dan dipelajari di dalam keluarga. Seorang anak yang dibesarkan oleh keluarga yang memiliki intensitas emosional yang tinggi maka akan mempengaruhi kecerdasan emosionalnya ketika ia dewasa. Pengasuhan dan pendidikan yang baik dari keluarga sangat diperlukan dalam membentuk kepribadian seorang anak. ${ }^{12}$ Orang tua memberikapergaulannya seharn pemahaman keagamaan baik dari segi aqidah, akhlak, dan muamalah.

${ }^{12}$ Qurratun Ayun, POLA ASUH ORANG TUA DAN METODE PENGASUHAN $D A L A M$ MEMBENTUK KEPRIBADIAN ANAK, Jurnal Thufula Vol 5 No 12017 
Bekal agama yang diberikan orang tua akan memberikan dompak positif bagi anak dalam pergaulan sehari-hari bahkan berdampak pada masa depan anak.

Pendidikan dalam keluarga merupakan pembentukan landasan kepribadian anak. Dengan demikian orang tua harus mengetahui muatan apa saja yang menjadi priorias dalam pendidikan anak-anak mereka. Orang tua memberika pemahaman agama ke pada anak, memberikan pengawasan dan control yang baik bagi pergaulan anak, dan memberika perhatian kepada anakanak.

Achmadi mengatakan materi pendidikan yang wajib diberikan keluarga kepada anak di masa golden age meliputi: (a) menanamkan iman dan tauhid; (b) menumbuhkan semangat bekerja dengan penuh kejujuran (c) menumbuhkan sikap hormat dan bakti pada orang tua; (d) mendorong anak untuk taat beribadah (terutama shalat); (e) menanamkan cinta kebenaran (ma'ruf) dan menjauhi yang buruk (mungkar); (f) menanamkan sikap hidup sederhana. Untuk menanamkan materi pendidikan tersebut di atas tidak mungkin hanya dengan perintah atau nasehat, larangan atau hukuman, tetapi akan lebih berhasil apabila dilakukan dengan memberi contoh dan iklim keluarga yang kondusif, karena anak suka meniru dan suka mencoba sendiri sebagai naluri kreatifitasnya. (h) menanamkan jiwa sabar dalam menghadapi cobaan; (g) menumbuhkan sikap rendah hati, tidak angkuh dan sombong dalam pergaulan. ${ }^{13}$

\section{KESIMPULAN}

Berdasarkan hasil penelitian dan pembahasan mengenai problematika orang tua dalam pembentukan akhlak di Desa Bukit Barisan Kec. Merigi Kab. Kepahiang, dapat disimpulkan sebagai berikut: Problematika yang dihadapi orang tua dalam pembentukan akhlak pada anak di Desa Bukit Barisan adalah kurangnya pemahaman tentang agama orang tua sehingga tidak tidak memiliki waktu untuk mengajari pengetahuan tentang agama kepada anaknya. Kemudian kurangnya pengawasan dari orang tua. Orang tua kurang mengawasi atau mengontrol kegiatan sehari-hari anak yang membuat anak merasa kurang perhatian dan merasa bebas untuk bertingkah laku. Untuk mengatasi problematika dalam pembentukan akhlak pada anak, orang tua di Desa Bukit Barisan melakukan upaya-upaya diantaranya: menambah ilmu pengetahuan agama Islam dengan menyekolahkan anak disekolah islam, membimbing anak untuk bergaul dengan orang-orang yang baik, menghilangkan sifat pemalas anak,

13 Idi Warsah, PENDIDIKAN KELUARGA MUSLIM DI TENGAH MASYARAKAT MULTI-AGAMA: ANTARA SIKAP KEAGAMAANDAN TOLERANSI (Studi di Desa Suro Bali Kepahiang-Bengkulu), Edukasia: Jurnal Penelitian Pendidikan Islam, Vol. 13, No. 1, Februari 2018 
merubah kebiasan buruk pada anak dan mengajarkan anak gemar membaca sejarah orang-orang ternama. Prophetic parenting atau Pola pengasuhan yang diajarkan Rasulullah yaitu: qudwah hasanah (contoh yang baik), al-adah (pembiasaan), manidzah basanah (nasihat yang baik), uqubah wa ujarah (proporsional), serta al-mulahadzah (perhatian).

Adapun saran-saran penulis sebagai berikut: Bagi Orang Tua: Peran orang tua dalam pembentukan akhlak pada anak sangat besar manfaatnya untuk menjadikan anak yang berakhlak mulia. Oleh karena itu, orang tua diharapkan untuk: Pertama, Dapat memanfaatkan waktunya untuk membentuk akhlak pada anak dengan sebaik-baiknya. Kedua, Orang tua untuk tetap mengawasi setiap aktifitas yang dilakukan anak. Orang tua harus memberi perhatian yang lebih dan memberi contoh teladan yang baik, bukan hanya mengarahkan saja. Kemudian sebagaimana lingkungan yang dapat membentuk perilaku anak, hendaknya anak juga dapat memberikan pengaruh positif ke lingkungannya. Selanjutnya orang tua bisa mencontoh metode mendidik yang baik yang Rasulullah lakukan kepada anak keturunannya.

\section{BIBLIOGRAFI}

Ariska, Yuni. Mohammad Afifulloh, Lia Nur Atiqoh Bela Dina. 2020. Peran Keluarga Dalam Pendidikan Akhlak Anak (Studi Kasus Anak Usia 6-12 Tahun Di Kelurahan Wonokoyo RT. 03 RW. 02 Malang). Vicratina: Jurnal Pendidikan Islam, Volume 5 Nomor 4

Ainiyah, Nur. 2013. Pembentukan Karakter Melalui Pendidikan Agama Islam. Jurnal Al-Ulum.

Ayun, Qurratun. 2017. Pola Asuh Orang Tua Dan Metode Pengasuhan Dalam Membentuk Kepribadian Anak, Jurnal Thufula Vol 5 No 1

Halimah, Siti. 2019. "Upaya Guru dalam Pembentukan Akhlak Anak di Raudlotul Athfal Baipas Roudlotul Jannah Kota Malang". Jurnal Dewantara.

Hairina, Yulia. 2016. Prophetic Parenting sebagai Model Pengasuhan dalam Pembentukan Karakter (Akhlak) Anak. Jurnal Studia Insania Vol No 1 2016.

H, Hanan. 2005. Anak Shalih, Investasi Dunia Akherat, Hidayatullah Edisi 03/XVIII/Juli.Rahman, Ulfiani. 2020. Karakteristik perkembangan Anka usia Dini, Jurnal Lentera Pendidikan Vol. 12 N0 1

Ru’iya, Sutipyo. Teguh Santoso Dody Sb, Herina Octaviani Saputri. 2021. Penguatan Prophetic Parenting Bagi Orangtua Di Kelurahan 
Patangpuluhan Wirobrajan Yogyakarta, Community Engagement \& Emergence Journal Volume 2 Nomor 2.

Taufiqurrahman, Muhammad. 2018. Prophetic Parenting Mencetak Pendidik Berkarakter Dalam Pendidikan Anak Usia Dini, Al Fitrah Journal Of Early Childhood Islamic Education Vol.1 No.2

Warsah, Idi. 2018. Pendidikan Keluarga Muslim Di Tengah Masyarakat MultiAgama: Antara Sikap Keagamaandan Toleransi (Studi di Desa Suro Bali Kepahiang-Bengkulu), Edukasi: Jurnal Penelitian Pendidikan Islam, Vol. 13, No. 1. 